\title{
Effect of Additives and Fuel Blending on Emissions and Ash-Related Problems from Small-Scale Combustion of Reed Canary Grass
}

\author{
Sébastien Fournel ${ }^{1,2, *}$, Joahnn H. Palacios ${ }^{2}$, Stéphane Godbout ${ }^{2}$ and Michèle Heitz ${ }^{1}$ \\ 1 Department of Chemical and Biotechnological Engineering, Université de Sherbrooke, \\ 2500 Université Boulevard, Sherbrooke QC J1K 2R1, Canada; \\ E-Mail: michele.heitz@usherbrooke.ca
}

2 Research and Development Institute for the Agri-Environment (IRDA), 2700 Einstein Street, Quebec City QC G1P 3W8, Canada; E-Mails: joahnn.palacios@irda.qc.ca (J.H.P.); stephane.godbout@irda.qc.ca (S.G.)

* Author to whom correspondence should be addressed; E-Mail: sebastien.fournel@usherbrooke.ca; Tel.: +1-418-654-3792; Fax: +1-418-654-2600.

Academic Editor: Stephen R. Smith

Received: 16 June 2015 / Accepted: 20 July 2015 / Published: 24 July 2015

\begin{abstract}
Agricultural producers are interested in using biomass available on farms to substitute fossil fuels for heat production. However, energy crops like reed canary grass contain high nitrogen $(\mathrm{N})$, sulfur $(\mathrm{S})$, potassium $(\mathrm{K})$ and other ash-forming elements which lead to increased emissions of gases and particulate matter (PM) and ash-related operational problems (e.g., melting) during combustion. To address these problematic behaviors, reed canary grass was blended with wood (50 wt $\%)$ and fuel additives $(3 \mathrm{wt} \%)$ such as aluminum silicates (sewage sludge), calcium (limestone) and sulfur (lignosulfonate) based additives. When burned in a top-feed pellet boiler $(29 \mathrm{~kW})$, the four blends resulted in a 17\%-29\% decrease of PM concentrations compared to pure reed canary grass probably because of a reduction of $\mathrm{K}$ release to flue gas. Nitrogen oxides $\left(\mathrm{NO}_{\mathrm{x}}\right)$ and sulfur dioxide $\left(\mathrm{SO}_{2}\right)$ emissions varied according to fuel $\mathrm{N}$ and $\mathrm{S}$ contents. This explains the lower $\mathrm{NO}_{\mathrm{x}}$ and $\mathrm{SO}_{2}$ levels obtained with wood based products and the higher $\mathrm{SO}_{2}$ generation with the grass/lignosulfonate blend. The proportion of clinkers found in combustion ash was greatly lessened $(27 \%-98 \%)$ with the use of additives, except for lignosulfonate. The positive effects of some additives may allow agricultural fuels to become viable alternatives.
\end{abstract}


Keywords: agricultural biomass combustion; energy crops; additives; fuel blending; pellets; gas emissions; particulate matter; ash-related problems; melting

\section{Introduction}

Substituting fossil fuels with renewable forms of energy has become a promising option to face the increase of greenhouse gas concentrations in the atmosphere and the rising cost of oil [1]. This context has motivated the shift to biomass for heat production since it offers many economic, social, and environmental benefits such as financial net saving, local employment opportunities and carbon dioxide $\left(\mathrm{CO}_{2}\right)$ emissions reduction compared to petroleum products [2]. In rural areas, there is a growing interest in using agricultural residues and energy crops grown on underutilized lands for heating farm facilities [2-4]. The latter represent moreover several ecological benefits including prevention of soil erosion, limited soil management, and low demand for nutrient inputs [5]. Although combustion is the most mature technology for biomass conversion, emissions from agricultural biomass combustion are generally greater than those from combustion of woody materials, which are the most common solid biofuels. Actually, agricultural biomass burned in small-scale appliances can significantly contribute to higher pollutants release such as particulate matter (PM), nitrogen oxides $\left(\mathrm{NO}_{\mathrm{x}}\right)$, sulfur dioxide $\left(\mathrm{SO}_{2}\right)$, and hydrogen chloride $(\mathrm{HCl})$ [6]. These contaminants can affect air quality and climate by causing respiratory and cardiovascular problems, acid rains, and absorption of solar radiation $[7,8]$.

Comparatively to wood, typical agricultural fuels have higher ash content and higher concentrations of inorganic elements such as nitrogen $(\mathrm{N})$, sulfur $(\mathrm{S})$, chlorine $(\mathrm{Cl})$, potassium $(\mathrm{K})$, and silicon $(\mathrm{Si})$. High amounts of $\mathrm{N}, \mathrm{S}$, and $\mathrm{Cl}$ in energy crops increase the emissions of $\mathrm{NO}_{\mathrm{x}}, \mathrm{SO}_{2}$, and $\mathrm{HCl}$, respectively. Ash is responsible for dust production and operational problems such as fouling, slagging, and corrosion, which may disturb the burning process, reduce efficiency and lead to unwanted shutdowns and higher levels of compounds from an incomplete combustion including carbon monoxide (CO) and PM [9,10]. Particles consist of aerosol-forming elements like $\mathrm{K}$ and $\mathrm{Cl}$, as well as sodium $(\mathrm{Na})$ and $\mathrm{S}$. Boiler corrosion and fouling are also directly related to alkali metals (K and $\mathrm{Na}$ ) and $\mathrm{Cl}$ contents. Chlorine acts as a catalyst, facilitating the movement of iron away from metal surfaces and the deposition of inorganic compounds. Sulfur and Si, in combination with alkali, lead to reactions associated with fouling and slagging in boilers. Potassium and, to a lesser extent, Si, S, and $\mathrm{Na}$, contribute to lower ash melting temperatures in dedicated energy crops [11-15].

Strategies which can be used to reduce pollutants release from agricultural biomass combustion include the use of air staging [16] or flue gas cleaning devices such as filters and electrostatic precipitators [6]. Since the primary cause of emissions is the elemental composition of the feedstock, an alternative, which does not imply possible modifications to the heating system and can act on ash-related problems, is modifying the biomass chemical properties through the use of additives or fuel blending [17]. Additives refer to a group of minerals or products that can alter the ash chemistry, convert problematic species to less troublesome forms and enhance the ash melting temperature in thermal processes. Additives can be introduced before combustion by blending them with the fuel prior 
to pelletizing the admixture produced [18]. Based on their reactive compounds, additives can be classified as aluminum silicates, calcium, or sulfur based additives [17-19].

Aluminum (Al) silicates based additives, such as kaolin, have been exhaustively studied and have shown an ability to abate particle emissions [11,17,20-24] and ash sintering [25-27] during combustion of agricultural crops and residues. Kaolin mainly acts by binding alkali compounds in ash and by forming $\mathrm{K}$ - or $\mathrm{Na}-\mathrm{Al}$ silicates that have a higher melting temperature than pure $\mathrm{K}$ or $\mathrm{Na}$ silicates [17-19]. Some works [20,23,28,29] also reported that the addition of kaolin almost eliminated $\mathrm{Cl}$ in fly-ash particles whereas $\mathrm{HCl}$ levels raised. As clay minerals additives, sewage sludge contains great amounts of Al-Si compounds, can increase ash sintering temperature and can reduce fouling deposition [18,30]. In addition, it has been suggested that $\mathrm{S}, \mathrm{Ca}$, and phosphorus $(\mathrm{P})$ comprised in sewage sludge may contribute to the capture and deposition of gaseous alkali chlorides $(\mathrm{KCl}$ or $\mathrm{NaCl}$ ) [30-32]. In fact, these gases can be transformed into sulfates, which are less deleterious deposits [31], or into high melting $\mathrm{K}$ - or Na-Ca phosphates [18,19,30]. Additives from waste stream resources such as sewage sludge are of particular interest since they are financially attractive [30]. Calcium based additives, such as lime and limestone, are used for reactions with $\mathrm{HCl}$ and $\mathrm{SO}_{2}$ and have been recognized as well as effective in reducing the slagging tendency in combustion systems by formation of high melting silicates formed of Ca, magnesium $(\mathrm{Mg})$, and alkali [18-20,23,26,27]. Co-firing biomass with calcium based additives actually creates a diluting effect on biomass ash, which restrains physical contact and thus sintering of ash particles [18,19]. Furthermore, lime is already and widely used in agriculture since it is one of the most crucial and beneficial components to successful crop management [33]. Sulfur based additives can decrease the formation of alkali chlorides through different sulfation reactions, as well as increase the melting point of deposits, hence preventing fouling of heat transfer surfaces $[18,19]$. For instance, the injection of ammonium sulfate greatly reduced gaseous $\mathrm{KCl}$ and produced sulfated deposits without any trace of $\mathrm{Cl}$. Concentrations of $\mathrm{SO}_{2}$ and $\mathrm{HCl}$ in flue gas were however higher when ammonium sulfate was added, while nitrogen monoxide (NO) emissions severely dropped because of selective non-catalytic reduction with ammonia $\left(\mathrm{NH}_{3}\right)$ [34]. Another option as a sulfur-based additive could be lignosulfonate, which is a by-product of the wood sulfite pulping process. So far, lignosulfonates are used in animal feeds and have been considered as the most effective and popular binding agents for pellets [35]. Their behavior and potential as combustion additives are uncertain since previous experiences showed that pellets with lignosulfonate result in problems with slag formation for wood [36] as well as in an anti-slagging effect for barley straw and husk [37].

Besides the addition of additives, mixing problematic feedstocks with good quality fuels, such as woody materials, may also improve thermal process and reduce emissions. The positive impact may be based on the diluting effect of the fuel having a lower ash content [18,38,39]. The burning of a blend composed of reed canary grass and wood chips only slightly raised fine particles, $\mathrm{NO}_{\mathrm{x}}$ and $\mathrm{SO}_{2}$ releases compared to wood alone, while $\mathrm{CO}$ and $\mathrm{HCl}$ either decreased or remained unchanged [38]. Nevertheless, different results from Lamberg et al. [39] showed elevated levels of incomplete combustion gases using similar wood-grass pellets.

This short review suggests that sewage sludge, limestone, lignosulfonate, and wood could be used as additives for mitigating particulate and gas emissions as well as ash-related operational problems in agricultural biomass heating systems. However, there is currently only a few scientific studies 
regarding the capacity of these additives to abate pollutant formation and sintering of energy crop ash. The present work was performed with the aim of measuring and comparing PM and gas production and evaluating the ash melting propensity during small-scale combustion of reed canary grass with and without additive (sewage sludge, limestone, lignosulfonate, and wood). This energy crop has a great development potential in the province of Quebec, Canada, but its high concentrations of S, Cl, K, and $\mathrm{Si}$ are responsible for increased levels of contaminants and clinkers [40]. The results obtained in this study can provide a better understanding of the effects of biomass-additive and biomass-biomass blending and their potential for controlling emissions and solving ash-related problems.

\section{Materials and Methods}

\subsection{Biomass Fuels, Additives, and Blends}

Pellets of reed canary grass and wood were respectively bought from agricultural producers (CLD Du Granit, Lac-Mégantic, QC, Canada) and a pellet mill (Trebio, Portage-du-Fort, QC, Canada). Both biomass fuels were milled (Wiley Mill 1885PL, Thomas Scientific, Swedesboro, NJ, USA) using a $4 \mathrm{~mm}$ screen size. Sewage sludge (Osons L'Osier, Rivière-du-Loup, QC, Canada) and lignosulfonate (Granulart, Neuville, QC, Canada) were acquired from research partners. Limestone came from a chemical company (Laboratoires MAT, Quebec City, QC, Canada). Lignosulfonate and limestone were in a powdered form.

The products were weighed on a dry basis and each of the individual blends (Table 1) was mixed manually and then pelletized (GRH200 pelletizer, Granulart, Neuville, QC, Canada). Sewage sludge (SS), limestone (LM) and lignosulfonate (LG) were added to reed canary grass (R) in a percentage of $3 \mathrm{wt} \%$ (blends R-SS, R-LM and R-LG, respectively). A review of the literature [10,11,20,22,24-27,29,30] showed that additives are generally blended with biomass in proportions up to $10 \mathrm{wt} \%$. However, satisfactory results were especially obtained by adding $1-5 \mathrm{wt} \%$ of additives. By analyzing available data, it seemed that the difference between $1 \mathrm{wt} \%$ and $3 \mathrm{wt} \%$ was slightly significant, whereas it was negligible between $3 \mathrm{wt} \%$ and $5 \mathrm{wt} \%$. Wood (W) was blended with reed canary grass in a 50-50 $\mathrm{wt} \%$ proportion (blend $\mathrm{R}-\mathrm{W}$ ). This choice of admixture was motivated through theoretical calculations which determined the optimal levels according to the guiding values of Obernberger et al. [9] on major components ( $\mathrm{N}, \mathrm{S}$, and $\mathrm{Cl}$ ) in solid biofuels for unproblematic combustion. Furthermore, pure wood and pure reed canary grass pellets were tested to serve as references.

Table 1. Description of the tested blends (expressed in wt $\%$ of the different products).

\begin{tabular}{ccccccc}
\hline & R & W & R-W & R-SS & R-LM & R-LG \\
\hline Reed canary grass (R) & 100 & 0 & 50 & 97 & 97 & 97 \\
Wood (W) & 0 & 100 & 50 & 0 & 0 & 0 \\
Sewage sludge (SS) & 0 & 0 & 0 & 3 & 0 & 0 \\
Limestone (LM) & 0 & 0 & 0 & 0 & 3 & 0 \\
Lignosulfonate (LG) & 0 & 0 & 0 & 0 & 0 & 3 \\
\hline
\end{tabular}


All blends were experienced only once because the availability of resources (biomass and additives) by the suppliers did not allow realizing more than one replication. Before each experiment, a sample of the tested blend was sent to the Research and Development Institute for the Agri-Environment (IRDA) scientific laboratory (Quebec City, QC, Canada) to determine the physico-chemical properties. A more detailed description of the laboratory methods used can be found in Fournel et al. [40].

Additionally, fuel indexes on a molar basis, based on works by Sommersacher et al. [27,41] and describing the effect of given elements on alkali release, corrosion risk and ash sintering temperature, were calculated. They correspond respectively to $\mathrm{Si} /(\mathrm{K}+\mathrm{Na}), 2 \mathrm{~S} / \mathrm{Cl}$ and $(\mathrm{Si}+\mathrm{P}+\mathrm{K}+\mathrm{Na}) /(\mathrm{Ca}+\mathrm{Mg}$ $+\mathrm{Al})$. Herein, the sum of alkali $(\mathrm{K}+\mathrm{Na})$ replaced the $\mathrm{K}$ factor in the original indexes to account for possible high $\mathrm{Na}$ contents in some admixtures.

\subsection{Combustion System}

The experimental tests were carried out at a research facility on bioenergy of IRDA (Deschambault, QC, Canada). This facility includes a combustion room in which was installed a commercial 29-kW furnace (BB-100, LEI Products, Madisonville, KY, USA). The BB-100 (Figure 1) is a top-fed, multi-fuel (wood, agricultural crops and residues, waste, etc.), hydronic (use of water as the heat-transfer medium), non-catalytic, and non-pressurized boiler.

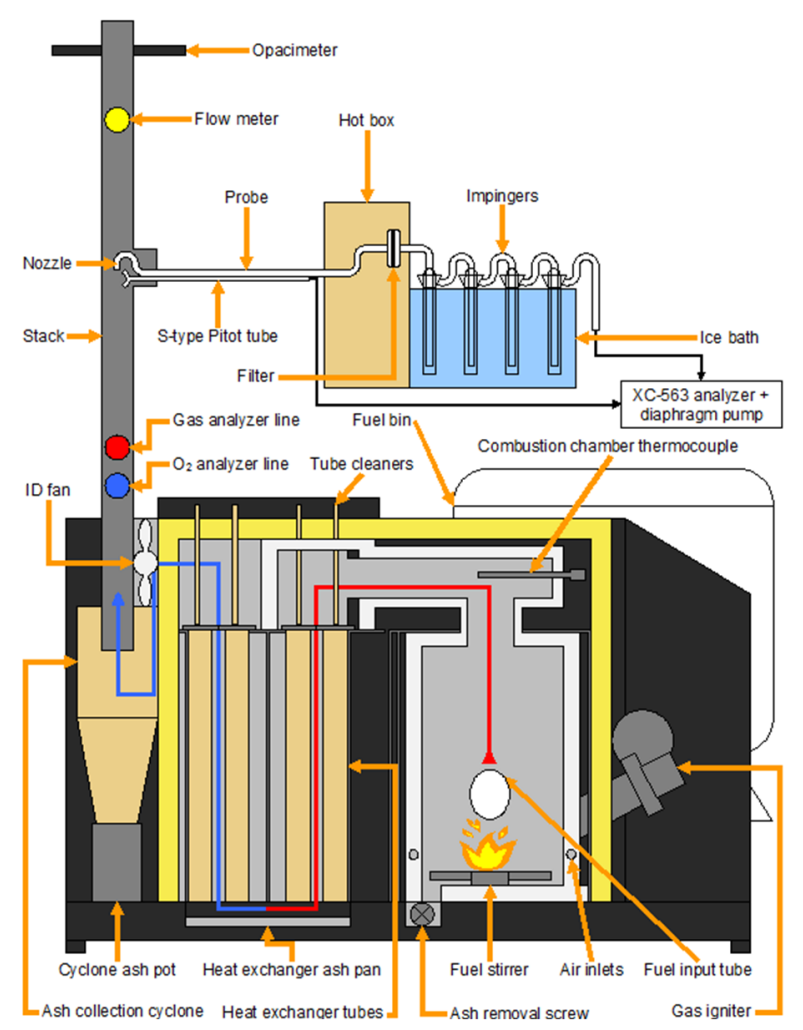

Figure 1. Schematic view of the boiler component parts and main sampling instruments.

The combustion was initiated by using a propane igniter. After reaching the intended temperature, restricted to $675^{\circ} \mathrm{C}$ in order to limit the formation of slags, the supply of fuel was instigated. The pellets were continuously supplied to the burning chamber from a storage tank by an auger screw. The overfed material which dropped into the combustion compartment from the fuel input tube was 
constantly mixed on the ceramic base plate by a fuel stirrer. This apparatus allowed a slow removal of ash to an ash tray in which an auger screw is installed. The air was supplied to the combustion chamber by an induced draft fan, located at the end of the flue gas stream behind the heat exchanger, which pulled up air from the outside inwards. The temperature, the supply rate of fuel and air as well as the frequency of ash removal were controlled by a user interface and regulated for each blend to reach a stable combustion regime, which was then sustained automatically by the boiler's internal computer. The produced heat energy was extracted to the circulating water in a heat exchanger. The feed and hot water temperatures were respectively maintained at $60{ }^{\circ} \mathrm{C}\left( \pm 3{ }^{\circ} \mathrm{C}\right)$ and $70{ }^{\circ} \mathrm{C}\left( \pm 3{ }^{\circ} \mathrm{C}\right)$. Exhaust gases were directed to an exhaust duct via an ash collection cyclone. The boiler finally contains a removable ash pan and pot under the heat exchanger and the cyclone system.

About $25 \mathrm{~kg}$ of biomass were burned during a typical 6-h experiment. Each test included a 1-h period for start-up (gas igniter in function), $2 \mathrm{~h}$ to reach steady-state combustion (setting of the optimal conditions) and $3 \mathrm{~h}$ for measurements and collecting data. All the results presented in the following sections correspond to the data collected during those last three hours.

\subsection{Gas and Particulate Measurements}

The flue gas was evacuated through a $4.5 \mathrm{~m}$ stack composed of double wall stove pipes of $150 \mathrm{~mm}$ in diameter. Sampling ports (Figure 1) were fixed along the pipes to install samplers and measuring instruments. The first one is an LC CEM O 2 analyzer (Ametek/Thermox, Pittsburgh, PA, USA) with an internal zirconium oxide cell. It was used to continuously monitor the oxygen $\left(\mathrm{O}_{2}\right)$ content of the flue gas. A Fourier transform infrared spectrometer (FTIR; FTLA2000, ABB Bomem, Quebec City, QC, Canada) was then used to constantly analyze concentrations of nine gases $\left(\mathrm{CO}_{2}, \mathrm{CO}, \mathrm{CH}_{4}, \mathrm{~N}_{2} \mathrm{O}\right.$, $\mathrm{NO}, \mathrm{NO}_{2}, \mathrm{NH}_{3}, \mathrm{SO}_{2}$, and $\mathrm{HCl}$ ) from flue gas samples during the experimental combustion tests. The flue gas samples were drawn with a diaphragm pump into a heated stainless steel tube. The IRGAS 100 software (CIC Photonics, Albuquerque, NM, USA) acquired the spectra and quantified the gases each minute. Both instruments were connected to a data logger (CR10X, Campbell Scientific, Edmonton, AB, Canada).

At a distance $1.6 \mathrm{~m}$ higher than the FTIR sampling line, the PM sampling train (Figure 1) was inserted. Total PM in the flue gas was sampled according to Method $5 \mathrm{H}$ proposed by the United States Environmental Protection Agency. Particles were thereby sampled isokinetically. The PM sampling line included a stainless steel nozzle (12.5 $\mathrm{mm}$ in diameter), a stainless steel probe (600 $\mathrm{mm}$ long), an S-type Pitot tube, a 75-mm glass fibre filter (Whatman 934-AH, GE Healthcare, Mississauga, ON, Canada) inserted into a Pyrex filter holder installed in a heated compartment maintained at $120{ }^{\circ} \mathrm{C}$, four impingers connected in series in an ice bath, a metering system (XC-563 Digital Meter Console, Apex Instruments, Fuquay-Varina, NC, USA) and a vacuum pump. More details on PM sampling method are given here [42].

An opacimeter (EMS750, Environmental Monitor Service, Yalesville, CT, USA) was installed $0.675 \mathrm{~m}$ above the last disturbance to continuously give an indication of opacity in real time. The exhaust gas velocity was monitored by a gas mass flow meter (GF90, Fluid Components Intl., San Marcos, CA, USA; error $\pm 1 \%$ ). 


\subsection{Ash Analyses}

The ashes collected from the removal screw under the burning chamber, the pan under the heat exchanger, and the pot under the cyclone system were removed the next day of test in the morning after ash had cooled during the night. The three sorts of ash were weighed and sampled. They were analyzed in the same manner than biomass fuels in Section 2.1. Combustion ash was totally sieved (4.75 $\mathrm{mm}$ ) before sampling to collect clinkers and to calculate the proportion of ash melted, according to the method used by Calvalho et al. [43].

\section{Results and Discussion}

\subsection{Blends Physico-Chemical Properties}

The higher heating value (HHV), moisture, ash content and elemental composition of each biomass fuel, additive and blend are presented in Table 2. Reed canary grass contained slightly less carbon (46.1 wt \% vs. $50.4 \mathrm{wt} \%)$ and high amounts of ash (6.6 wt $\%$ vs. $0.8 \mathrm{wt} \%)$ compared to wood, which resulted in a lower HHV (17.2 MJ $\mathrm{kg}^{-1}$ vs. $\left.19.5 \mathrm{MJ} \cdot \mathrm{kg}^{-1}\right)$. Main differences in inorganic elements between both fuels were high concentrations of $\mathrm{N}, \mathrm{S}, \mathrm{Cl}, \mathrm{K}$, and $\mathrm{Si}$ in reed canary grass. These elevated quantities, combined with relatively low $\mathrm{Ca}, \mathrm{Mg}$, and $\mathrm{Al}$ contents, can lead to higher levels of $\mathrm{NO}_{\mathrm{x}}$ and ash-related operational problems, as suggested by fuel indexes (Table 3). The addition of additives or fuel blending with wood should alter the chemical composition of reed canary grass to limit these inconveniences.

Table 2. Physico-chemical properties of biomass fuels, additives and blends (dry basis for all parameters, except for moisture on wet basis).

\begin{tabular}{|c|c|c|c|c|c|c|c|c|c|}
\hline & \multicolumn{2}{|c|}{ Biomass } & \multicolumn{3}{|c|}{ Additive } & \multicolumn{4}{|c|}{ Blend } \\
\hline & $\mathbf{R}$ & $\mathbf{W}$ & SS & $\mathbf{L M}$ & $\mathbf{L G}$ & $\mathbf{R}-\mathbf{W}$ & R-SS & R-LM & R-LG \\
\hline $\mathrm{HHV}\left(\mathrm{MJ} \cdot \mathrm{kg}^{-1}\right)$ & 17.2 & 19.5 & 8.0 & n.a. & 17.0 & 18.0 & 17.3 & 16.7 & 17.2 \\
\hline Moisture (wt\%) & 8.9 & 6.1 & 59.9 & 0.2 & 5.8 & 8.2 & 8.6 & 8.2 & 7.4 \\
\hline Ash (wt\%) & 6.6 & 0.8 & 36.7 & 57.8 & 25.7 & 4.3 & 7.2 & 9.1 & 7.4 \\
\hline $\mathrm{C}(\mathrm{wt} \%)$ & 46.1 & 50.4 & 19.0 & 11.9 & 42.7 & 47.8 & 45.7 & 45.0 & 45.8 \\
\hline $\mathrm{H}(\mathrm{wt} \%)$ & 6.8 & 6.8 & 3.8 & 0.2 & 4.9 & 6.8 & 6.7 & 6.5 & 6.6 \\
\hline $\mathrm{O}(\mathrm{wt} \%)$ & 48.8 & 48.4 & 14.6 & 30.1 & 30.2 & 49.1 & 48.2 & 46.6 & 46.7 \\
\hline $\mathrm{N}(\mathrm{wt} \%)$ & 0.89 & 0.14 & 1.65 & 0.06 & 1.06 & 0.61 & 0.90 & 0.90 & 0.90 \\
\hline $\mathrm{S}\left(\mathrm{mg} \cdot \mathrm{kg}^{-1}\right)$ & 1686 & 256 & 4269 & 0 & 81,219 & 1013 & 1553 & 1582 & 3805 \\
\hline $\mathrm{Cl}\left(\mathrm{mg} \cdot \mathrm{kg}^{-1}\right)$ & 1226 & 167 & 105 & 32 & 6035 & 753 & 1219 & 1180 & 1218 \\
\hline $\mathrm{K}\left(\mathrm{mg} \cdot \mathrm{kg}^{-1}\right)$ & 9099 & 840 & 2584 & 21 & 754 & 5291 & 8511 & 8535 & 8813 \\
\hline $\mathrm{Na}\left(\mathrm{mg} \cdot \mathrm{kg}^{-1}\right)$ & 25 & 82 & 199 & 3780 & 80,885 & 46 & 29 & 121 & 2384 \\
\hline $\mathrm{Si}\left(\mathrm{mg} \cdot \mathrm{kg}^{-1}\right)$ & 10,696 & 623 & 46,765 & 30 & 57 & 6648 & 11,295 & 10,818 & 10,973 \\
\hline $\mathrm{P}\left(\mathrm{mg} \cdot \mathrm{kg}^{-1}\right)$ & 2510 & 93 & 26,923 & 1 & 30 & 1370 & 2528 & 2315 & 2404 \\
\hline $\mathrm{Ca}\left(\mathrm{mg} \cdot \mathrm{kg}^{-1}\right)$ & 4053 & 3252 & 10,277 & 388,815 & 1187 & 3191 & 3497 & 13,729 & 3995 \\
\hline $\operatorname{Mg}\left(\mathrm{mg} \cdot \mathrm{kg}^{-1}\right)$ & 1575 & 400 & 4555 & 211 & 226 & 998 & 1409 & 1437 & 1530 \\
\hline $\mathrm{Al}\left(\mathrm{mg} \cdot \mathrm{kg}^{-1}\right)$ & 281 & 231 & 55,194 & 0 & 13 & 235 & 931 & 255 & 268 \\
\hline
\end{tabular}

Notes: n.a., not applicable; HHV, higher heating value. 
Table 3. Fuel indexes $\left(\mathrm{mol} \cdot \mathrm{mol}^{-1}\right)$ describing alkali release $(\mathrm{Si} /(\mathrm{K}+\mathrm{Na}))$, corrosion risk $(2 \mathrm{~S} / \mathrm{Cl})$ and ash sintering temperature $((\mathrm{Si}+\mathrm{P}+\mathrm{K}+\mathrm{Na}) /(\mathrm{Ca}+\mathrm{Mg}+\mathrm{Al}))$.

\begin{tabular}{lcccccc}
\hline & R & W & R-W & R-SS & R-LM & R-LG \\
\hline $\mathrm{Si} /(\mathrm{K}+\mathrm{Na})$ & 1.63 & 0.88 & 1.72 & 1.84 & 1.72 & 1.19 \\
$2 \mathrm{~S} / \mathrm{Cl}$ & 3.04 & 3.38 & 2.98 & 2.82 & 2.96 & 6.91 \\
$(\mathrm{Si}+\mathrm{P}+\mathrm{K}+\mathrm{Na}) /(\mathrm{Ca}+\mathrm{Mg}+\mathrm{Al})$ & 3.95 & 0.47 & 3.23 & 3.91 & 1.66 & 4.62 \\
\hline
\end{tabular}

Note: alkali release, corrosion risk and ash sintering temperature decrease with increasing index value.

Sewage sludge, limestone, and lignosulfonate respectively comprised high concentrations of $\mathrm{Al}$ $\left(55,194 \mathrm{mg} \cdot \mathrm{kg}^{-1}\right)$ and Si $\left(46,765 \mathrm{mg} \cdot \mathrm{kg}^{-1}\right), \mathrm{Ca}\left(388,815 \mathrm{mg} \cdot \mathrm{kg}^{-1}\right)$, and $\mathrm{S}\left(81,219 \mathrm{mg} \cdot \mathrm{kg}^{-1}\right)$. Sodium amount is also present in a similar quantity than $\mathrm{S}$ in lignosulfonate $\left(80,885 \mathrm{mg} \cdot \mathrm{kg}^{-1}\right)$. These characteristics affected fuel indexes (Table 3$)$ as $\mathrm{Si} /(\mathrm{K}+\mathrm{Na})$ ratio slightly increased for each blend except for R-LG blend, $2 \mathrm{~S} / \mathrm{Cl}$ ratio doubled for $\mathrm{R}-\mathrm{LG}$ blend and $(\mathrm{Si}+\mathrm{P}+\mathrm{K}+\mathrm{Na}) /(\mathrm{Ca}+\mathrm{Mg}+\mathrm{Al})$ ratio considerably improved for R-LM blend and worsened for R-LG blend. Mixing reed canary grass and wood in equal proportion diluted the problematic elements of the former biomass as $\mathrm{R}-\mathrm{W}$ blend contained approximately half of $\mathrm{S}, \mathrm{Cl}, \mathrm{K}$, and $\mathrm{Si}$ (Table 2). For this reason, fuel indexes were predominantly improved.

\subsection{Gas and Particulate Emissions}

The highest PM level was obtained from pure reed canary grass pellets (1182 $\mathrm{mg} \cdot \mathrm{Nm}^{-3}$; Table 4). Pure wood pellets, in comparable combustion conditions, produced almost half of this amount $\left(621 \mathrm{mg} \cdot \mathrm{Nm}^{-3}\right)$. Their lower ash content and thus their lower concentrations in ash-forming elements such as $\mathrm{K}, \mathrm{S}$, and $\mathrm{Cl}$ (Table 2) may be the reason for this reduction in PM. The four blends emitted between $835 \mathrm{mg} \cdot \mathrm{Nm}^{-3}$ and $983 \mathrm{mg} \cdot \mathrm{Nm}^{-3}$, signifying that additives allowed a decrease of particles ranging from $17 \%$ to $29 \%$ compared to pure reed canary grass. These numbers almost correspond with particle drops $(31 \%-57 \%)$ obtained by Bäfver et al. [20], Tissari et al. [11] and Carroll and Finnan [17] when kaolin was added (2-5 wt\%) to agricultural products (oat grain, miscanthus, or tall fescue). As the latter authors stated, addition of additives with very low concentration of $\mathrm{K}$ or high amounts of $\mathrm{Al}$ and $\mathrm{Si}$ counteracts $\mathrm{K}$ volatilization from energy crops during the heating process and thus reduces PM emissions. Since most of the additives used within this study enhanced to some extent the alkali release index (Table 3), K may have been retained in combustion ash (see Section 3.4) rather than been volatilized as fly ash. Besides, PM ensuing from the mixing of reed canary grass with a woody material was only 1.3 -fold greater than pure wood. This result is supported by the findings of Kortelainen et al. [38] and Lamberg et al. [39] where aerosol levels from different R-W blends were 1.4 times on average those of wood alone. This indicated that co-combustion of reed canary grass with wood could be an option for small-scale boilers which are capable of operating with fuels comprising moderate quantities of ash [38].

Emissions of $\mathrm{CO}_{2}$ varied between $137,929 \mathrm{mg} \cdot \mathrm{Nm}^{-3}$ and $143,021 \mathrm{mg} \cdot \mathrm{Nm}^{-3}$ without particular trend (Table 4). The CO levels were $208 \mathrm{mg} \cdot \mathrm{Nm}^{-3}$ for wood pellets, whereas they reached between $356 \mathrm{mg} \cdot \mathrm{Nm}^{-3}$ and $431 \mathrm{mg} \cdot \mathrm{Nm}^{-3}$ for grass-containing pellets. Methane $\left(\mathrm{CH}_{4}\right)$, nitrous oxide $\left(\mathrm{N}_{2} \mathrm{O}\right)$ and $\mathrm{NH}_{3}$ were only produced in small amounts $\left(<4 \mathrm{mg} \cdot \mathrm{Nm}^{-3}\right)$ without significant differences between fuels. Sometimes, concentrations were even near the detection limit of the FTIR so that no value was 
recorded. The measured $\mathrm{NO}_{\mathrm{x}}$ emissions were correlated with fuel $\mathrm{N}$, showing that $\mathrm{NO}_{\mathrm{x}}$ are mainly formed from the feedstock $\mathrm{N}$ as other works revealed [39-41]. Actually, $\mathrm{NO}_{\mathrm{x}}$ levels ranged from $63 \mathrm{mg} \cdot \mathrm{Nm}^{-3}$ for wood $(0.14 \mathrm{wt} \% \mathrm{~N})$ to $229 \mathrm{mg} \cdot \mathrm{Nm}^{-3}$ on average for R, R-SS, R-LM and R-LG blends $(0.90 \mathrm{wt} \% \mathrm{~N})$ with R-W blend $(0.61 \mathrm{wt} \% \mathrm{~N})$ in the middle $\left(185 \mathrm{mg} \cdot \mathrm{Nm}^{-3}\right)$. Therefore, the amount of additive ( $3 \mathrm{wt} \%$ ) was not high enough to have a real impact on $\mathrm{NO}_{\mathrm{x}}$ concentrations. However, mixing two quality-contrasting fuels together (R-W blend) reduced $\mathrm{NO}_{x}$ emissions by almost $20 \%$. Similarly, $\mathrm{SO}_{2}$ varied according to fuel $\mathrm{S}$ as observed in Figure 2. In this figure, the value for R-LM blend slightly deviates from the main linear correlation. In fact, high $\mathrm{Ca}$ content can have a strong influence on retention of $\mathrm{S}$ in combustion ash since some authors [31,44,45] reported that Ca reacts with $\mathrm{SO}_{2}$ to form $\mathrm{Ca}$ sulfates. This $\mathrm{S}$ capture by $\mathrm{Ca}$ compounds, which cut $\mathrm{SO}_{2}$ emissions, was possibly predominant during R-LM burning as the mass balance on S (see Section 3.4) revealed that most of S is indeed comprised in combustion ash. Besides, the addition of lignosulfonate (R-LG blend) radically increased $\mathrm{SO}_{2}$ levels (Table 2) and the corrosion risk index (Table 3) compared to pure reed canary grass. As mentioned before, the raise of $\mathrm{SO}_{2}$ was a consequence of the addition of a sulfur based additive which, in return, was supposed to decrease the formation of alkali chlorides through sulfation reactions $[18,19]$. By analyzing the $\mathrm{Cl}$ mass balance (see Section 3.4), less $\mathrm{Cl}$ was present in deposits under the heat exchanger and cyclone. Usually, $\mathrm{HCl}$ emissions would be also increased [34], but no real $\mathrm{HCl}$ values were recorded by the FTIR.

Table 4. Gas and particulate emissions $\left(\mathrm{mg} \cdot \mathrm{Nm}^{-3}\right.$ at $\left.13 \mathrm{vol} \% \mathrm{O}_{2}\right)$.

\begin{tabular}{ccccccc}
\hline & $\mathbf{R}$ & $\mathbf{W}$ & $\mathbf{R}-\mathbf{W}$ & $\mathbf{R}-\mathbf{S S}$ & $\mathbf{R}-\mathbf{L M}$ & R-LG \\
\hline $\mathrm{CO}$ & 383 & 208 & 409 & 356 & 431 & 357 \\
$\mathrm{CO}_{2}$ & 140,106 & 137,929 & 143,021 & 138,418 & 139,257 & 139,184 \\
$\mathrm{CH}_{4}$ & 3.58 & 3.40 & 3.30 & 3.18 & 3.52 & 4.33 \\
$\mathrm{~N}_{2} \mathrm{O}$ & 1.64 & n.a. & n.a. & 2.38 & 0.77 & 1.23 \\
$\mathrm{NH}_{3}$ & n.a. & 0.15 & 0.02 & 0.03 & 0.06 & n.a. \\
$\mathrm{NO}_{\mathbf{x}}$ & 222 & 63 & 185 & 221 & 234 & 239 \\
$\mathrm{SO}_{2}$ & 137 & 16 & 66 & 139 & 73 & 423 \\
$\mathrm{HCl}$ & n.a. & n.a. & n.a. & n.a. & n.a. & n.a. \\
$\mathrm{PM}$ & 1182 & 621 & 835 & 892 & 955 & 983 \\
\hline
\end{tabular}

Notes: n.a., not applicable.

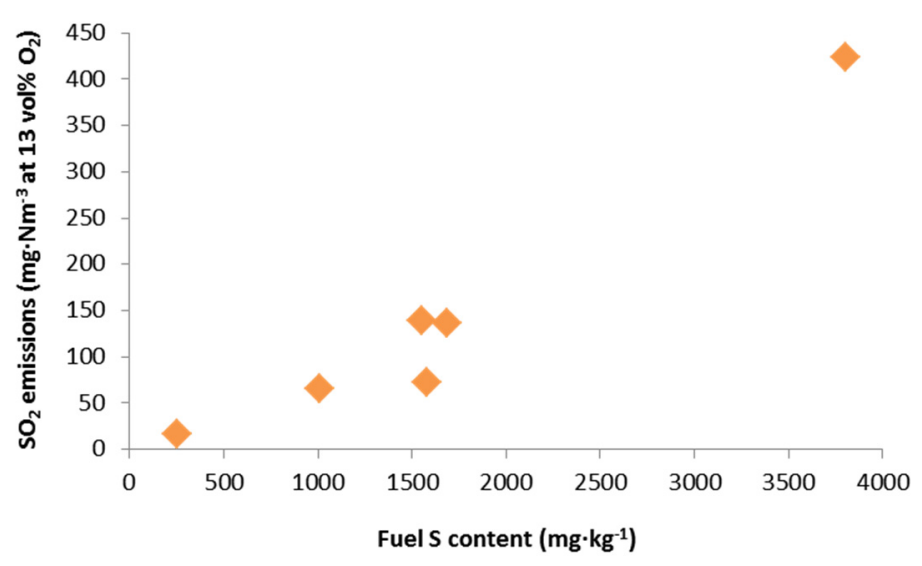

Figure 2. Correlation between $\mathrm{SO}_{2}$ emissions and fuel $\mathrm{S}$ content. 


\subsection{Ash Melts}

Combustion chamber ash sieving allowed the calculation of the proportion of melted ash (Table 5). No sintered ash was collected after wood burning, whereas the reference value obtained with reed canary grass was $3.90 \mathrm{wt} \%$. Mixing this energy crop with wood $(2.84 \mathrm{wt} \%)$ only reduced ash agglomeration by $27 \%$. The best results were reached with sewage sludge $(0.87 \mathrm{wt} \%)$ and limestone (0.07 wt $\%)$ additions. The 78\%-98\% sintering reductions when using these additives can be attributed to a surplus of $\mathrm{Ca}$, which contributed to dilute R-LM ash, or a change from relatively low fusion temperature silicates and phosphates to higher fusion temperature silicates and phosphates [24-26,30]. Similar slag formation decreases $(51 \%-67 \%)$ were noted by Xiong et al. [25] with $3 \mathrm{wt} \%$ addition of kaolin and calcite to corn stovers. These results were due to an increase by $100-200{ }^{\circ} \mathrm{C}$ of ash melting temperature. Moreover, the $(\mathrm{Si}+\mathrm{P}+\mathrm{K}+\mathrm{Na}) /(\mathrm{Ca}+\mathrm{Mg}+\mathrm{Al})$ ratio (Table 3$)$ serving to estimate the ash sintering temperature was either greatly lessened (R-W and R-LM) or remained unchanged (R-SS) for blends with positive effects. On the contrary, R-LG blend resulted in a severe raise of molten ash proportion (40\%). The high concentration of the alkali Na likely led to a melting point decline (Table 3) as Steenari et al. [26] experienced with the use of sodium bicarbonate as combustion additive.

Table 5. Proportion of melted ash.

\begin{tabular}{lcccccc}
\hline & R & W & R-W & R-SS & R-LM & R-LG \\
\hline Melted ash (wt\%) & 3.90 & 0.00 & 2.84 & 0.87 & 0.07 & 5.48 \\
Difference with R (\%) & n.a. & -100 & -27 & -78 & -98 & +40 \\
\hline
\end{tabular}

Notes: n.a., not applicable.

\subsection{Ash Analyses}

Table 6 presents the content in minor elements of the three sorts of ash. In the case of combustion chamber ash, significant differences were only noticeable regarding $\mathrm{Na}, \mathrm{Ca}$, and $\mathrm{Al}$ amounts for R-LG (11.3 $\left.\mathrm{g} \cdot \mathrm{kg}^{-1}\right)$, R-LM $\left(86.4 \mathrm{~g} \cdot \mathrm{kg}^{-1}\right)$ and R-SS $\left(9.3 \mathrm{~g} \cdot \mathrm{kg}^{-1}\right)$ blends, respectively. These elevated levels were directly linked with additive addition and can be correlated with the results of Table 5 . The greater presence of $\mathrm{Ca}$ and $\mathrm{Al}$ silicates limited clinkers formation, whereas $\mathrm{Na}$ intensified ash agglomeration.

In ash collected under the heat exchanger tubes, $\mathrm{S}, \mathrm{Cl}$, and $\mathrm{K}$ concentrations drastically increased compared to combustion ash, indicating the importance of alkali volatilization. Excluding pure wood, blends with sewage sludge and limestone were those with the lower $\mathrm{K}$ quantities in heat exchanger ash $\left(67-73 \mathrm{~g} \cdot \mathrm{kg}^{-1}\right)$ and the higher $\mathrm{K}$ levels in combustion ash $\left(44-49 \mathrm{~g} \cdot \mathrm{kg}^{-1}\right)$. This showed the impact of $\mathrm{Al}$ silicates and $\mathrm{Ca}$ on $\mathrm{K}$ adsorption. Besides, the effect of lignosulfonate was also very clear since $\mathrm{S}$ and $\mathrm{Na}$ contents were high within R-LG heat exchanger ash.

In cyclone ash, only few elements were noteworthy. Calcium concentration was unsurprisingly high for R-LM blend while $\mathrm{Cl}, \mathrm{Na}$, and $\mathrm{Al}$ amounts were high in wood. No particular reason can explain this last result.

The proportion of fuel $\mathrm{S}, \mathrm{Cl}$, and $\mathrm{K}$ found in the three sorts of ash is illustrated in Figure 3 . As explained before, limestone addition allowed a greater retention of $\mathrm{S}$ in combustion ash compared to 
the other blends. Lignosulfonate generated an increase of $\mathrm{SO}_{2}$ and fused ash, but reduced the presence of $\mathrm{Cl}$ in deposits under the heat exchanger and cyclone. Finally, additives adsorbed more $\mathrm{K}$ in combustion ash than pure reed canary grass.
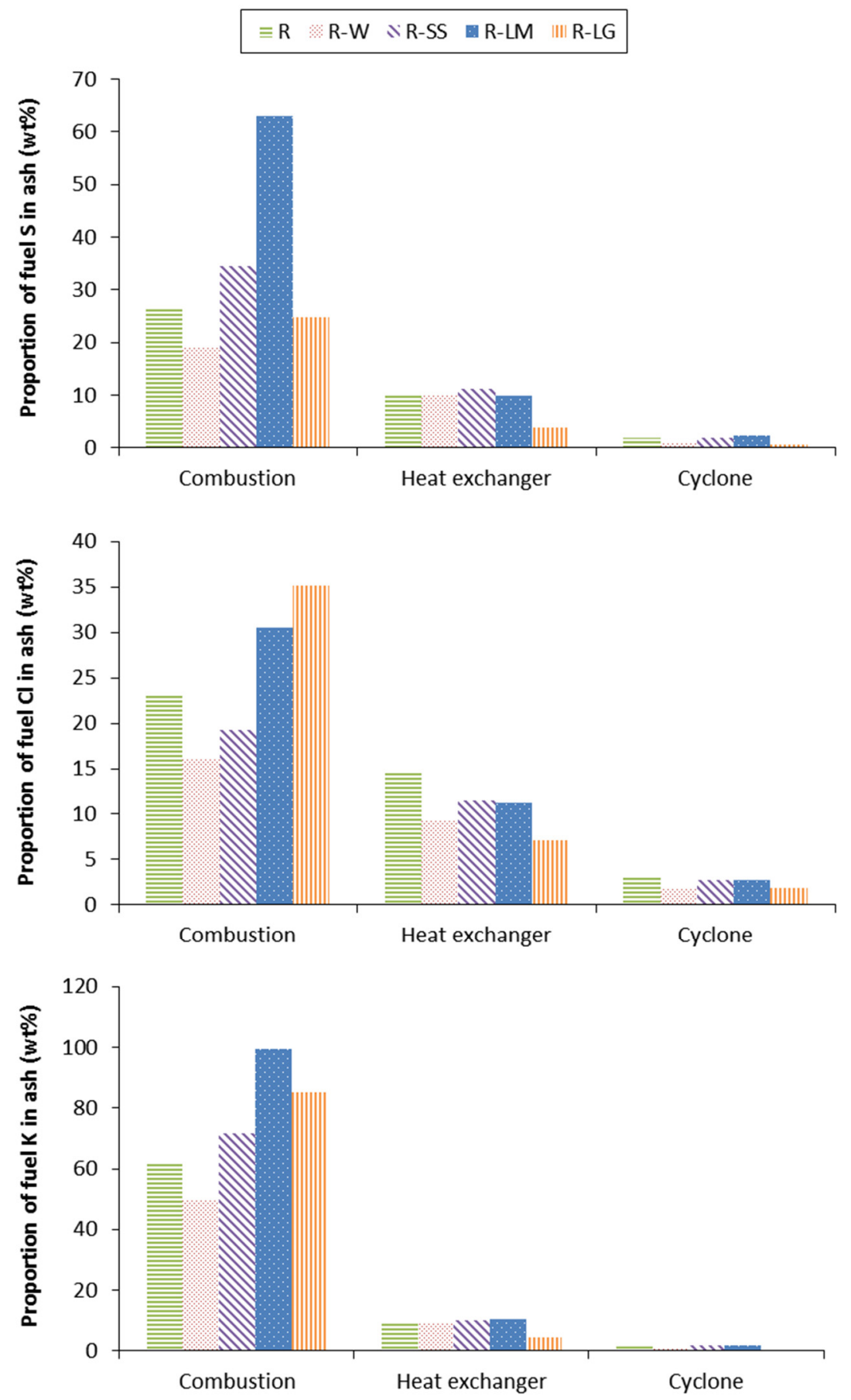

Figure 3. Proportion of fuel $\mathrm{S}, \mathrm{Cl}$ and $\mathrm{K}$ found in combustion, heat exchanger and cyclone ash. 
Table 6. Chemical composition of combustion, heat exchanger and cyclone ash (dry basis).

\begin{tabular}{|c|c|c|c|c|c|c|}
\hline & $\mathbf{R}$ & $\mathbf{W}$ & R-W & R-SS & R-LM & R-LG \\
\hline \multicolumn{7}{|c|}{ Combustion Ash } \\
\hline $\mathrm{S}\left(\mathrm{g} \cdot \mathrm{kg}^{-1}\right)$ & 3.4 & 1.1 & 2 & 3.9 & 5.8 & 5.2 \\
\hline $\mathrm{Cl}\left(\mathrm{g} \cdot \mathrm{kg}^{-1}\right)$ & 2.2 & 0.7 & 1.2 & 1.7 & 2.1 & 2.4 \\
\hline $\mathrm{K}\left(\mathrm{g} \cdot \mathrm{kg}^{-1}\right)$ & 43.2 & 12 & 26.9 & 44 & 49.4 & 41.8 \\
\hline $\mathrm{Na}\left(\mathrm{g} \cdot \mathrm{kg}^{-1}\right)$ & 0.7 & 1.1 & 0.6 & 1.3 & 1.7 & 11.3 \\
\hline $\mathrm{Si}\left(\mathrm{g} \cdot \mathrm{kg}^{-1}\right)$ & 13.4 & 1.6 & 7.2 & 15.4 & 14 & 12.4 \\
\hline $\mathrm{P}\left(\mathrm{g} \cdot \mathrm{kg}^{-1}\right)$ & 22.1 & 30.4 & 18.5 & 23.1 & 86.4 & 21.6 \\
\hline $\mathrm{Ca}\left(\mathrm{g} \cdot \mathrm{kg}^{-1}\right)$ & 8 & 5.1 & 5.4 & 8.3 & 8.8 & 7.3 \\
\hline $\operatorname{Mg}\left(g \cdot \mathrm{kg}^{-1}\right)$ & 2.8 & 3.8 & 2.2 & 9.3 & 3.1 & 2.6 \\
\hline $\mathrm{Al}\left(\mathrm{g} \cdot \mathrm{kg}^{-1}\right)$ & 3.4 & 1.1 & 2 & 3.9 & 5.8 & 5.2 \\
\hline \multicolumn{7}{|c|}{ Heat Exchanger Ash } \\
\hline $\mathrm{S}\left(\mathrm{g} \cdot \mathrm{kg}^{-1}\right)$ & 15.2 & 17.3 & 16.5 & 14.8 & 11.8 & 29 \\
\hline $\mathrm{Cl}\left(\mathrm{g} \cdot \mathrm{kg}^{-1}\right)$ & 16.4 & 9.4 & 11.5 & 12 & 9.9 & 17.6 \\
\hline $\mathrm{K}\left(\mathrm{g} \cdot \mathrm{kg}^{-1}\right)$ & 80.8 & 33.8 & 76.7 & 72.6 & 66.6 & 75.5 \\
\hline $\mathrm{Na}\left(\mathrm{g} \cdot \mathrm{kg}^{-1}\right)$ & 2.3 & 9.4 & 3.3 & 3.7 & 3.1 & 18.2 \\
\hline $\mathrm{Si}\left(\mathrm{g} \cdot \mathrm{kg}^{-1}\right)$ & 28.8 & 8.5 & 27.1 & 28.3 & 28.5 & 25.9 \\
\hline$P\left(g \cdot \mathrm{kg}^{-1}\right)$ & 54.9 & 138.7 & 79.7 & 54.3 & 190.8 & 71 \\
\hline $\mathrm{Ca}\left(\mathrm{g} \cdot \mathrm{kg}^{-1}\right)$ & 19.6 & 19.1 & 21.9 & 18.6 & 18.1 & 16.3 \\
\hline $\operatorname{Mg}\left(\mathrm{g} \cdot \mathrm{kg}^{-1}\right)$ & 7.4 & 28.5 & 10.4 & 12.3 & 7.1 & 6.9 \\
\hline $\mathrm{Al}\left(\mathrm{g} \cdot \mathrm{kg}^{-1}\right)$ & 15.2 & 17.3 & 16.5 & 14.8 & 11.8 & 29 \\
\hline \multicolumn{7}{|c|}{ Cyclone Ash } \\
\hline $\mathrm{S}\left(\mathrm{g} \cdot \mathrm{kg}^{-1}\right)$ & 10.6 & 14.3 & 10 & 10.9 & 10.7 & 15.3 \\
\hline $\mathrm{Cl}\left(\mathrm{g} \cdot \mathrm{kg}^{-1}\right)$ & 13.3 & 25.2 & 12.3 & 13 & 9.9 & 18.2 \\
\hline $\mathrm{K}\left(\mathrm{g} \cdot \mathrm{kg}^{-1}\right)$ & 63.8 & 38.1 & 47.9 & 56.9 & 44.8 & 47.8 \\
\hline $\mathrm{Na}\left(\mathrm{g} \cdot \mathrm{kg}^{-1}\right)$ & 2.8 & 13.1 & 2.7 & 5 & 2.4 & 8.1 \\
\hline $\mathrm{Si}\left(\mathrm{g} \cdot \mathrm{kg}^{-1}\right)$ & 33 & 8.4 & 27.6 & 31.7 & 28.3 & 27.1 \\
\hline $\mathrm{P}\left(\mathrm{g} \cdot \mathrm{kg}^{-1}\right)$ & 77.5 & 140.7 & 97.1 & 89.8 & 200.8 & 133.3 \\
\hline $\mathrm{Ca}\left(\mathrm{g} \cdot \mathrm{kg}^{-1}\right)$ & 23.3 & 20.3 & 25 & 22.2 & 20 & 19.7 \\
\hline $\operatorname{Mg}\left(\mathrm{g} \cdot \mathrm{kg}^{-1}\right)$ & 9.6 & 35.8 & 11 & 10.9 & 8.2 & 8.9 \\
\hline $\mathrm{Al}\left(\mathrm{g} \cdot \mathrm{kg}^{-1}\right)$ & 10.6 & 14.3 & 10 & 10.9 & 10.7 & 15.3 \\
\hline
\end{tabular}

\section{Conclusions}

This study showed the effect of additives such as sewage sludge, limestone, lignosulfonate, and wood on particle and gaseous emissions and on ash sintering during small-scale combustion of reed canary grass. The four created blends resulted in PM decrease due to reduction of K release. Levels of $\mathrm{NO}_{\mathrm{x}}$ and $\mathrm{SO}_{2}$ respectively depended on fuel $\mathrm{N}$ and $\mathrm{S}$. The proportion of ash melts was greatly lessened with wood blending and the addition of sewage sludge or limestone because of a change of ash chemistry (higher ash sintering temperature compounds). Consequently, blending an energy crop with wood, sewage sludge, or limestone could be a promising strategy to handle problematic properties of agricultural biomass in small-scale heating systems and to help it compete favorably with wood pellets. 


\section{Acknowledgments}

The authors thank the Mitacs Accelerate program and the "Fonds de recherche du Québec" for their financial contributions. The authors gratefully acknowledge the Research and Development Institute for the Agri-Environment, Granulart, Agriculture and Agri-Food Canada and Université de Sherbrooke which provided in-kind contributions for this study. The authors also recognize the technical and professional support provided by IRDA research staff (Jean-Pierre Larouche, Cédric Morin, Michel Côté, Christian Gauthier and Patrick Dubé).

\section{Author Contributions}

All authors conceived and designed the experiments. Sébastien Fournel and Joahnn H. Palacios performed the experimental tests. All authors analyzed the data. Sébastien Fournel wrote the paper. All authors revised the article.

\section{Conflicts of Interest}

The authors declare no conflict of interest.

\section{References}

1. Dhillon, R.S.; von Wuehlisch, G. Mitigation of global warming through renewable biomass. Biomass Bioenergy 2013, 48, 75-89.

2. Saidur, R.; Abdelaziz, E.A.; Demirbas, A.; Hossain, M.S.; Mekhilef, S. A review on biomass as a fuel for boilers. Renew. Sustain. Energy Rev. 2011, 15, 2262-2289.

3. Lewandowski, I.; Scurlock, J.M.O.; Lindvall, E.; Christou, M. The development and current status of perennial rhizomatous grasses as energy crops in the US and Europe. Biomass Bioenergy 2003, 25, 335-361.

4. Brodeur, C.; Cloutier, J.; Crowley, D.; Desmeules, X.; Pigeon, S.; St-Arnaud, R.M. La Production de Biocombustibles Solides à partir de Biomasse Résiduelle ou de Cultures Énergétiques; Ministère de l'Agriculture, des Pêcheries et de l'Alimentation du Québec: Quebec City, QC, Canada, 2008; pp. 1-14.

5. McKendry, P. Energy production from biomass (Part 1): Overview of biomass. Bioresour. Technol. 2002, 83, 37-46.

6. Nussbaumer, T. Combustion and co-combustion of biomass: Fundamentals, technologies and primary measures for emission reduction. Energy Fuels 2003, 17, 1510-1521.

7. Williams, A.; Jones, J.M.; Ma, L.; Pourkashanian, M. Pollutants from the combustion of solid biomass fuels. Prog. Energy Combust. 2012, 38, 113-137.

8. Van Loo, S.; Koppejan, J. The Handbook of Biomass Combustion and Co-firing; Earthscan: London, UK, 2008; pp. 291-303.

9. Obernberger, I.; Brunner, T.; Bärnthaler, G. Chemical properties of solid biofuels-Significance and impact. Biomass Bioenergy 2006, 30, 973-982.

10. Werther, J.; Saenger, M.; Hartgem, E.U.; Ogada, T.; Siagi, Z. Combustion of agricultural residues. Prog. Energy Combust. 2000, 26, 1-27. 
11. Tissari, J.; Sippula, O.; Kouki, J.; Vuorio, K.; Jokiniemi, J. Fine particle and gas emissions from the combustion of agricultural fuels fired in a $20 \mathrm{~kW}$ burner. Energy Fuels 2008, 22, 2033-2042.

12. Jenkins, B.M.; Baxter, L.L.; Miles, T.R., Jr.; Miles, T.R. Combustion properties of biomass. Fuel Process. Technol. 1998, 54, 17-46.

13. Baxter, L.L.; Miles, T.R.; Miles, T.R., Jr.; Jenkins, B.M.; Milne, T.; Dayton, D.; Bryers, R.W.; Oden, L.L. The behavior of inorganic material in biomass-fired power boilers: Field and laboratory experiences. Fuel Process. Technol. 1998, 54, 47-78.

14. Cherney, J.H.; Verma, V.K. Grass pellet Quality Index: A tool to evaluate suitability of grass pellets for small scale combustion systems. Appl. Energy 2013, 103, 679-684.

15. Vassilev, S.V.; Baxter, D.; Vassileva, C.G. An overview of the behaviour of biomass during combustion: Part II. Ash fusion and ash formation mechanisms of biomass types. Fuel 2014, 117, $152-183$.

16. Carroll, J.P.; Finnan, J.M.; Biedermann, F.; Brunner, T.; Obernberger, I. Air staging to reduce emissions from energy crop combustion in small scale applications. Fuel 2015, 155, 37-43.

17. Carroll, J.P.; Finnan, J.M. The use of additives and fuel blending to reduce emissions from the combustion of agricultural fuels in small scale boilers. Biosyst. Eng. 2015, 129, 127-133.

18. Wang, L.; Hustad, J.E.; Skreiberg, Ø.; Skjevrak, G.; Grønli, M. A critical review on additives to reduce ash related operation problems in biomass combustion applications. Energy Procedia 2012, 20, 20-29.

19. Shao, Y.; Wang, J.; Preto, F.; Zhu, J.; Xu, C. Ash deposition in biomass combustion or co-firing for power/heat generation. Energies 2012, 5, 5171-5189.

20. Bäfver, L.S.; Rönnbäck, M.; Leckner, B.; Claesson, F.; Tullin, C. Particle emission from combustion of oat grain and its potential reduction by addition of limestone or kaolin. Fuel Process. Technol. 2009, 90, 353-359.

21. Bäfver, L.; Boman, C.; Rönnbäck, M. Reduction of Particle Emissions by Using Additives. Available online: http://www.ieabcc.nl/workshops/task32_2011_graz_aerosols/04_Bafver.pdf (accessed on 30 January 2015).

22. Boman, C.; Boström, D.; Öhman, M. Effect of Fuel Additive Sorbents (Kaolin and Calcite) on Aerosol Particle Emission and Characteristics during Combustion of Pelletized Woody Biomass. Available online: http://pure.ltu.se/portal/files/2208136/22._Effect_of_fuel_additives_on_particle_ characteristics_Valencia_2008.pdf (accessed on 30 January 2015).

23. Boström, D.; Grimm, A.; Boman, C.; Björnbom, E.; Öhman, M. Influence of kaolin and calcite additives on ash transformations in small-scale combustion of oat. Energy Fuels 2009, 23, 5184-5190.

24. Öhman, M.; Hedman, H.; Boström, D.; Nordin, A. Effect of kaolin and limestone addition on slag formation during combustion of wood fuels. Energy Fuels 2004, 18, 1370-1376.

25. Xiong, S.; Burvall, J.; Örberg, H.; Kalen, G.; Thyrel, M.; Öhman, M.; Boström, D. Slagging characteristics during combustion of corn stovers with and without kaolin and calcite. Energy Fuels 2008, 22, 3465-3470.

26. Steenari, B.-M.; Lundberg, A.; Pettersson, H.; Wilewska-Bien, M.; Andersson, D. Investigation of ash sintering during combustion of agricultural residues and the effect of additives. Energy Fuels 2009, 23, 5655-5662. 
27. Sommersacher, P.; Brunner, T.; Obernberger, I.; Kienzl, N.; Kanzian, W. Application of novel and advanced fuel characterization tools for the combustion related characterization of different wood/kaolin and straw/kaolin mixtures. Energy Fuels 2013, 27, 5192-5206.

28. Aho, M. Reduction of chlorine deposition in FB boilers with aluminium-containing additives. Fuel 2001, 80, 1943-1951.

29. Aho, M.; Silvennoinen, J. Preventing chlorine deposition on heat transfer surfaces with aluminium-silicon rich biomass residue and additive. Fuel 2004, 83, 1299-1305.

30. Wang, L.; Skjevrak, G.; Hustad, J.E.; Skreiberg, O. Investigation of biomass ash sintering characteriscs and the effet of additives. Energy Fuels 2014, 28, 208-218.

31. Åmand, L.-E.; Leckner, B.; Eskilsson, D.; Tullin, C. Deposits on heat transfer tubes during co-combustion of biofuels and sewage sludge. Fuel 2006, 85, 1313-1322.

32. Pettersson, A.; Zevenhoven, M.; Steenari, B.-M.; Åmand, L.-E. Application of chemical fractionation methods for characterisation of biofuels, waste derived fuels and CFB co-combustion fly ashes. Fuel 2008, 87, 3183-3193.

33. Paradelo, R.; Virto, I.; Chenu, C. Net effect of liming on soil organic carbon stocks: A review. Agric. Ecosyst. Environ. 2015, 202, 98-107.

34. Kassman, H.; Pettersson, J.; Steenari, B.-M.; Åmand, L.-E. Two strategies to reduce gaseous $\mathrm{KCl}$ and chlorine in deposits during biomass combustion-Injection of ammonium sulphate and co-combustion with peat. Fuel Process. Technol. 2013, 105, 170-180.

35. Tarasov, D.; Shahi, C.; Leitch, M. Effect of additives on wood pellet physical and thermal characteristics: A review. ISRN Forestry 2013, 2013, 1-6.

36. Nikolaisen, L.; Jensen, T.N.; Hjuler, K.; Busk, J.; Junker, H.; Sander, B.; Baxter, L.; Bloch, L. Quality Characteristics of Biofuel Pellets; Danish Technological Institute: Aarhus, Denmark, 2002; p. 24.

37. Skjevrak, G. Wood Pellets Utilized in the Commercial and Residential Sectors-An In-depth Study of Selected Barriers for Increased Use; Norwegian University of Science and Technology: Trondheim, Norway, 2013; p. 130.

38. Kortelainen, M.; Jokiniemi, J.; Nuutinen, I.; Torvela, T.; Lamberg, H.; Karhunen, T.; Tissari, J.; Sippula, O. Ash behaviour and emission formation in a small-scale reciprocating-grate combustion reactor operated with wood chips, reed canary grass and barley straw. Fuel 2015, 143, $80-88$.

39. Lamberg, H.; Tissari, J.; Jokiniemi, J.; Sippula, O. Fine particle and gaseous emissions from a small-scale boiler fueled by pellets of various raw materials. Energy Fuels 2013, 27, 7044-7053.

40. Fournel, S.; Palacios, J.H.; Morissette, R.; Villeneuve, J.; Godbout, S.; Heitz, M.; Savoie, P. Influence of biomass properties on technical and environmental performance of a multi-fuel boiler during on-farm combustion of energy crops. Appl. Energy 2015, 141, 247-259.

41. Sommersacher, P.; Brunner, T.; Obernberger, I. Fuel Indexes: A novel method for the evaluation of relevant combustion properties of new biomass fuels. Energy Fuels 2012, 26, 380-390.

42. Fournel, S.; Palacios, J.H.; Morissette, R.; Villeneuve, J.; Godbout, S.; Heitz, M.; Savoie, P. Particulate concentrations during on-farm combustion of energy crops of different shapes and harvest seasons. Atmos. Environ. 2015, 104, 50-58. 
43. Carvalho, L.; Wopienka, E.; Pointner, C.; Lundgren, J.; Verma, V.K.; Haslinger, W.; Schmidl, C. Performance of a pellet boiler fired with agricultural fuels. Appl. Energy 2013, 104, 286-296.

44. Theis, N.; Skrifvars, B.J.; Zevenhoven, M.; Hupa, M.; Tran, H. Fouling tendency of ash resulting from burning mixtures of biofuels. Part 2: Deposit chemistry. Fuel 2006, 85, 1992-2001.

45. Pisupati, S.V.; Bhalla, S. Influence of calcium content of biomass-based materials on simultaneous $\mathrm{NO}_{x}$ and $\mathrm{SO}_{2}$ reduction. Environ. Sci. Technol. 2008, 42, 2509-2514.

(C) 2015 by the authors; licensee MDPI, Basel, Switzerland. This article is an open access article distributed under the terms and conditions of the Creative Commons Attribution license (http://creativecommons.org/licenses/by/4.0/). 